\title{
回転形位相調整機による風力発電設備の出力変動安定化
}

$\begin{array}{lcccc}\text { 正員 宮崎 } & \text { 保幸* } & \text { 正員 石月 } & \text { 照之* } \\ \text { 正員 工藤 } & \text { 俊明* } & \text { 正 員 影山 } & \text { 隆久* } \\ \text { 非会員 南波 } & \text { 聡* }^{*} & \text { 正 員 野呂 } & \text { 康宏* } \\ \text { 正員 嶋田 } & \text { 隆一** } & & & \end{array}$

\section{Application of Rotary Phase Shifter as Power Compensator for Wind Power Generators}

Yasuyuki Miyazaki*, Member, Teruyuki Ishizuki*, Member, Toshiaki Kudor*, Member, Takahisa Kageyama*, Member, Satoshi Namba*, Non-member, Yasuhiro Noro*, Member, Ryuichi Shimada**, Member

The renewable energy resources depend on the natural condition and are difficult to be considered as a stable power source. Moreover, the renewable energy plants tend to be distributed on the demand side and they are difficult to be governed at the central control station. So, the improvements of stabilizing and compensating distributed power system are required to realize the stable power operation.

This paper describes the effort of application of the Rotary Phase Shifter, which is an phase shifting equipment based on the induction machine technique, as an compensator for the power fluctuation of renewable energy resources, such as wind power stations. It is verified through computer simulation and factory examination using 50 kVA-prototype machine connected to the power system simulator with MG set controlled as a wind turbine generator.

キーワード : 電力系統, 位相調整機, 風力発電機

Keywords: electric power systems, phase shifter, wind turbine generator

\section{1. はじめに}

京都議定書の $\mathrm{CO}_{2}$ 削減目標達成，地球環境保全の対策と して, 風力, 太陽光などの再生可能エネルギーの有効活用を 促進する必要がある。近年の電力自由化やグリーン電力制 度の発足に伴い, 2010 年の風力発電導入目標 300 万 $\mathrm{kW}$ に 向け風力発電システムの電力系統への連系がますます増加 していくと考えられる。しかしながら，風力発電システム は出力変動が大きい電源であり, 出力変動の電力系統への 影響の問題が風力発電システムの普及の障害となっている 出力変動を運転側で制御できない風力発電システムの電力 系統への連系量か増大すると，電力需要に関係なく供給電 力が大きく変動し, 系統周波数や系統電圧などの電力品質

\footnotetext{
* (株) 東芝

于 183-8511 府中市東芝町 1

Toshiba Corporation

1, Toshiba-cho, Fuchu 183-8511

** 東京工業大学

厂 152-8550 東京都目黑区大岡山 2-12-1

Tokyo Institute of Technology

2-12-1, Ookayama, Meguro-ku, Tokyo 152-8550
}

の悪化を招くしたがって電力会社は電力系統への風力発電 システムの導入量を制限せざるを得ない状況となっている 風力発電システムの電力供給安定化は, 風力発電システム の導入促進の為により重要度か増している。従来の風力発 電システムの電力供給安定化方策として，風車側でのピッ チ制御や可变速運転機の採用, 電力貯蔵装置, 開閉器と抵 抗器による電力消費が考えられていたが, 応答速度の問題, 大幅なコスト増，制御精度の面で適用が進んでいない(1)(2)。

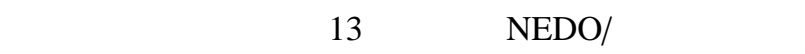
助成を受け,より安価で風力発電機の出力変動に対し適当な 応答特性を有するシステムとして巻線形誘導機の基本構造 を持つ回転形位相調整機 (Rotary Phase Shifter : 以下 RPS と記す） ${ }^{(3) \sim(7)}$ による電力変動補償装置の実用化開発を進め ている。RPS は炎の構造上, 有害な高調波の流出が極めて 少なく過電流耐量も大きい。これは実系統への適用に際し 重要な特長である。本稿では, RPS を電力変動補償装置と して使用する場合の理論説明と，風力発電システムに適用 した場合の計算機シミュレーションによる性能評価, およ び風力発電機の出力変動特性を再現可能な発電機を有する 模擬送電線設備に $50 \mathrm{kVA}$ RPS 試作機を接続した性能検証 
試験結果について述べる。

\section{2. 回転形位相調整機 ( RPS) の原理}

図 1 に示すように, RPS は巻線形誘導機と光の回転子駆 動装置とから成る回転形の移相装置である ${ }^{(3)(4)}$ 。本稿では RPS の回転子と固定子間で变化させる電気角を移相角と表 記する。一般的に RPS の固定子と回転子は異なる系統に接 続する。図 1 は固定子を商用系統に接続し，回転子をウィ ンドファームのようなパワープラントに接続した例である。 以下, 図 1 の巻線形誘導機は 2 極機として説明する。

RPS の基本特性は誘導機の特性式で表され，固定子上の 静止座標系での電圧方程式は次式となる ${ }^{(3)(4)}$ 。

$$
\left[\begin{array}{c}
\mathbf{v}_{s} \\
\mathbf{v}_{r}
\end{array}\right]=\left[\begin{array}{cc}
R_{s}+p L_{s} & p M \\
\left(p-j \omega_{m}\right) M & R_{r}+\left(p-j \omega_{m}\right) L_{r}
\end{array}\right]\left[\begin{array}{c}
\mathbf{i}_{s} \\
\mathbf{i}_{r}
\end{array}\right]
$$

ここで， $\mathbf{v}_{s}, \mathbf{v}_{r}, \mathbf{i}_{s}, \mathbf{i}_{r}$ は固定子と回転子の瞬時電圧およ び瞬時電流のベクトル， $R_{s}, R_{r}, L_{s}, L_{r}$ は固定子と回転子 の抵抗と巻線の自己インダクタンス， $M$ は相互インダクタ ンス, $p$ は微分演算子, $\omega_{m}$ は回転子回転角速度,$j$ は虚数 単位である。

(1) 式から固定子入力パワー $P_{s}$ と回転子入力パワー $P_{r}$ の関係式が次のように得られる。

$$
\begin{aligned}
P_{s}+P_{r}= & {\left[\begin{array}{ll}
\mathbf{i}_{s} & \mathbf{i}_{r}
\end{array}\right] \cdot\left[\begin{array}{c}
\mathbf{v}_{s} \\
\mathbf{v}_{r}
\end{array}\right] } \\
= & R_{s}\left|\mathbf{i}_{s}\right|^{2}+R_{r}\left|\mathbf{i}_{r}\right|^{2} \\
& +p\left\{\frac{1}{2} L_{s}\left|\mathbf{i}_{s}\right|^{2}+\frac{1}{2} L_{r}\left|\mathbf{i}_{r}\right|^{2}+M \mathbf{i}_{s} \cdot \mathbf{i}_{r}\right\} \\
& +\omega_{m} M\left(-j \mathbf{i}_{s}\right) \cdot \mathbf{i}_{r} \ldots \ldots \ldots \ldots \ldots \ldots
\end{aligned}
$$

上式右辺第 3 項は巻線の誘導性エネルギーの微分であり， 定常状態では 0 である。第 4 項が回転子軸機械出力パワー $P_{m}$ であり， $R_{s}$ と $R_{r}$ を無視すれば次の関係式が得られる。

$$
P_{s}+P_{r}=P_{m}=\omega_{m} T_{e}
$$

ただし， $T_{e}$ は回転子軸に発生する電気トルクで ある。

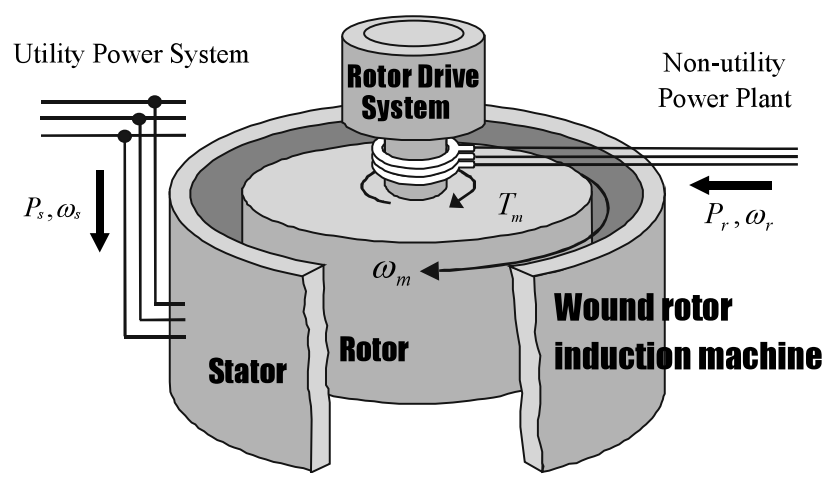

図 1 RPS の概念構成図

Fig. 1. Conceptual configuration of RPS.
損失を無視した場合の $P_{s}$ は同期ワットに等しく，固定子 電圧の角周波数が $\omega_{s}$ のとき $P_{s}$ は次式で表される。

$$
P_{s}=\omega_{s} \cdot T_{e}
$$

(3) 式と (4) 式からパワーに関する以下の関係式が得られる。

$$
\begin{aligned}
& P_{r}=-\left(\omega_{s}-\omega_{m}\right) T_{e}=-\left(\omega_{s}-\omega_{m}\right) P_{s} / \omega_{s}=-s P_{s} \\
& \text { n.m........... (5) } \\
& P_{m}=P_{s}+P_{r}=(1-s) P_{s} \\
& \text { ここで, } s=\left(\omega_{s}-\omega_{m}\right) / \omega_{s} \text { はすべりである。 }
\end{aligned}
$$

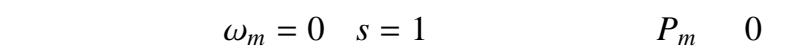
あり, RPS の通過パワー $P_{s}=-P_{r}$ に比例した電気トルク $T_{e}$ が回転子軸に発生する。この電気トルク $T_{e}$ により回転 子は回転力を得るが, 電気トルク $T_{e}$ と等しいトルク $T_{m}$ を 駆動装置で発生させ電気卜ルク $T_{e}$ を打ち消すことにより 回転子の停止状態が維持される。この場合，回転子の回転 角度が指令角度となるよう駆動装置によるトルク $T_{m}$ を制 御すると, 移相角を連続的に変化できる移相機として機能 する。

また，回転子回転角速度 $\omega_{m}$ を一定に制御すると，回転 子側角周波数は $\omega_{s}-\omega_{m}$ （すべり角周波数 : $s \omega_{s}$ ) となる。 この場合，RPS は周波数変換機として機能する。

このようにRPS は，駆動装置の制御により移相機，また は周波数変換機として適用することが可能である。

\section{RPS の構成と適用}

風力発電や太陽光発電など再生可能エネルギーを利用し た分散型電源では, 風の変動や日射量の変動により発電出 力が変動し, これによって連系した系統の短絡容量が小さ い場合には大きな電圧変動を発生させる可能性がある。例 えば配電線の末端に発電所が接続された場合, 変動抑制対 策が必要となる。著者らはこのような変動抑制を目的とし て，前章で述べた RPS を用いたシステムを提案する。

RPS の適用は大きく分けて二つの形態が考えられる。一 つは直列方式であり，もう一つは並列方式である。これら 二方式の概念図を図 2 に示す。図 2(a) は直列方式の構成を 示すものであり，RPS は二つの電力系統間に直列に接続さ れる。RPS は回転子に結合された回転子駆動装置で回転子 の回転角度または回転角速度, すなわち, 電力系統 1 と電力 系統 2 の間の位相差または周波数差を調整する。したがっ て, 直列方式の構成は非同期連系装置や周波数変換装置, 電力潮流制御装置として機能する。一方，図 2(b) は並列方 式の RPS 構成である。RPS は電力系統 1 と電力系統 2 を 連系する送電線に並列に接続されており，さらに，RPS の 回転子と固定子の間にインピーダンス要素が接続されてい る。このインピーダンス要素がリアクトルまたはコンデン サの場合 , 並列型 RPS システムは回転子の回転角度調整に より移相角を変化させ可変の無効電力調整装置として動作 する。従って , システムは電力系統の電圧変動を抑制する 


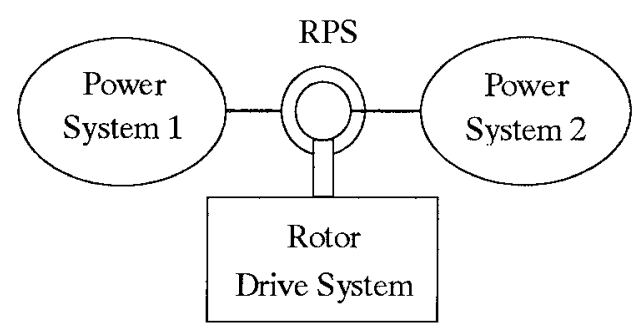

(a) Configuration of series type RPS

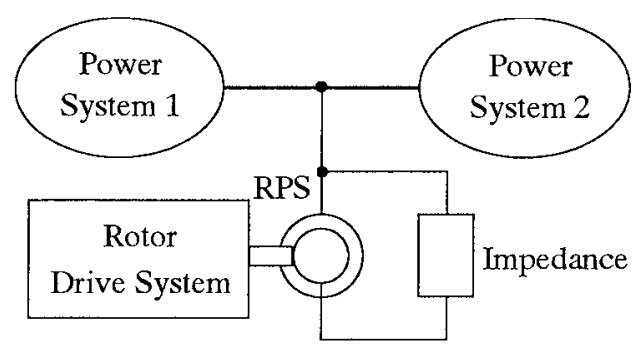

(b) Configuration of shunt type RPS

图 2 RPS 適用形態の概念図

Fig. 2. Two types of compensator with RPS.

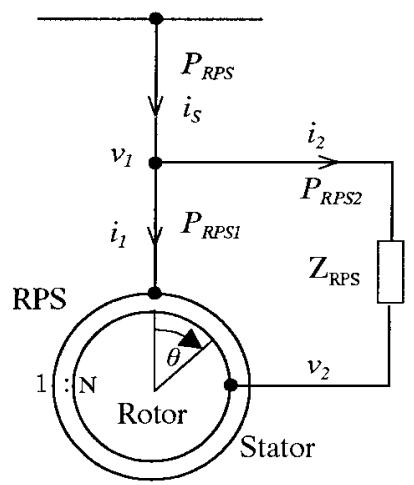

図 3 並列型 RPS の動作モデル

Fig. 3. Model of shunt type RPS.

ように動作させることができる。インピーダンス要素とし て抵抗を用いる方法も考えられ，RPS システムは回転子の 回転角度調整により，抵抗で消費する有効電力を連続可変 調整することができる。従って，RPS システムは可変抵抗 として動作し，風力発電を代表とする再生可能エネルギー による発電システムから生じる過剩な電力変動を吸収する ことが可能である。

並列型 RPS の動作原理を以下に説明する。図 3 に示す 回路で，RPS の漏れインピーダンスや励磁電流を無視した 理想的な RPS を考える。固定子巻線に対する回転子巻線の 巻数比 $N$ を 1 , 極数を 2 とし, RPS の回転子駆動装置によ り回転子の回転角度，即ち移相角を $\theta$ (系統電圧と等価で ある固定子側電圧位相を基準に回転子側電圧位相が $\theta$ 進み の意) としている状態とする。

系統電圧のベクトル $v_{1}$ に虚軸をおいた座標系で表すと， RPS の固定子側（1 次側），回転子側（2 次側）の電圧べク トルは光れ荘れ，

$$
\left.\begin{array}{l}
v_{1}=j V \\
v_{2}=j V e^{j \theta}
\end{array}\right\}
$$

とおくことができる。ここで，Vは電圧べクトルの大きさ とし，jは虚数単位である。RPS に並列に接続した回路の インピーダンスを $Z_{R P S}$ と置くと, 2 次電流 $i_{2}$ は (7) 式を利 用し次式で与えることができる。

$$
i_{2}=\frac{v_{1}-v_{2}}{Z_{R P S}}=j \frac{V}{Z_{R P S}}\left(1-e^{j \theta}\right) \cdots
$$

2 次電流 $i_{2}$ で作られる起磁力は 1 次側 (固定子側) では $\theta$ 遅れた方向となり，关の起磁力を打ち消すよう 1 次電流 $i_{1}$ が流れるので, 1 次電流 $i_{1}$ は (9) 式で与えられる。

$$
i_{1}=-i_{2} e^{-j \theta}=j \frac{V}{Z_{R P S}}\left(1-e^{-j \theta}\right)
$$

(8) 式と (9) 式より，RPS システムの補償電流 $i_{s}$ は次式 で与えられる。

$$
i_{s}=i_{1}+i_{2}=2 j \frac{V}{Z_{R P S}}(1-\cos \theta) .
$$

(10) 式は , RPS システム全体の等価インピーダンス $Z_{s}$ が 次式で与えられ，移相角 $\theta$ の関数として連続的に調整でき ることを示している。

$$
Z_{s}=\frac{v_{1}}{i_{s}}=\frac{Z_{R P S}}{2(1-\cos \theta)} .
$$

RPS の並列インピーダンス $Z_{R P S}$ として抵抗を用いた場 合には, $Z_{R P S}=R$ となり, RPS システム全体の入力電力 $P_{R P S}, 1$ 次巻線の入力電力 $P_{R P S 1}, 2$ 次巻線の入力電力 $P_{R P S 2}$ は弚れ光れ，

$$
\begin{aligned}
& P_{R P S}=V \cdot \operatorname{Im}\left(i_{s}\right)=\frac{2 V^{2}}{R}(1-\cos \theta) \cdots \\
& P_{R P S 1}=V \cdot \operatorname{Im}\left(i_{1}\right)=\frac{V^{2}}{R}(1-\cos \theta)=\frac{P_{R P S}}{2} \\
& P_{R P S 2}=V \cdot \operatorname{Im}\left(i_{2}\right)=\frac{V^{2}}{R}(1-\cos \theta)=\frac{P_{R P S}}{2} \\
& =P_{R P S 1}
\end{aligned}
$$

で計算され，回転子軸に発生する電気トルク $T_{e}$ は系統の角 周波数を $\omega_{1}$ とすると次式となる。

$$
T_{e}=\frac{P_{P R S 1}}{\omega_{1}}=\frac{V^{2}}{\omega_{1} R}(1-\cos \theta)
$$

RPS を変動抑制装置として動作させるのに必要な回転子 駆動装置の発生トルク $T_{m}$ は $-T_{e}$ で与えられる。

なお，巻数比を $N$ とした場合，(11) 式の RPS システム 全体の等価インピーダンスは次式で与えられる。

$$
Z_{s}=\frac{v_{1}}{i_{s}}=\frac{Z_{R P S}}{\left(N^{2}+1-2 N \cos \theta\right)}
$$

巻数比が 1 でない場合においても移相角 $\theta$ の関数として 連続的に RPS 全体の等価インピーダンス $Z s$ を調整できる。

(16) 式から, 移相角 $\theta$ の変化に対し $Z s$ の変化幅が最大 となるのは $N=1$ の場合であるので, 並列型 RPS の巻数 比 $N$ は 1 か望まれる。 


\section{RPS の本体設計}

RPS 本体は , 基本的に巻線形の誘導電動機と酷似してい る為, RPS 本体の等価回路は図 4 に示す $\mathrm{T}$ 型等価回路で表 すことができる。

等価回路に従い，並列型及び直列型について产れ光れ回 転子側を 1 次側として検討し，試設計を実施した。

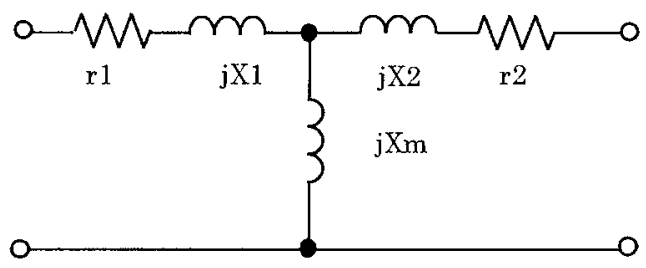

図 4 回転形位相調整機の等価回路

Fig. 4. Equivalent circuit of RPS.

表 1 RPS の諸定数一覧

Table 1. Constants of RPS (X2 and r2 parameters are referred to primary winding)

\begin{tabular}{|c|c|c|c|c|}
\hline & Unit & $\begin{array}{c}\text { Shunt } \\
\text { Type }\end{array}$ & $\begin{array}{c}\text { Series } \\
\text { Type }\end{array}$ & $\begin{array}{c}\text { Prototype } \\
\text { (both as shunt } \\
\text { and series) }\end{array}$ \\
\hline Capacity & kVA & 190 & 30615 & 50 \\
\hline X 1 & p.u. & 0.0764 & 0.1082 & 0.092 \\
\hline X 2 & p.u. & 0.0742 & 0.0948 & 0.082 \\
\hline Xm & p.u. & 4.039 & 20.582 & 7.13 \\
\hline r 1 & $\Omega$ at $75^{\circ} \mathrm{C}$ & 0.0181 & 0.0019 & 0.0368 \\
\hline r 2 & $\Omega$ at $75^{\circ} \mathrm{C}$ & 0.0237 & 0.0020 & 0.0418 \\
\hline $\begin{array}{c}\text { ratio } \\
\text { (Rotor/Stator) }\end{array}$ & - & 0.873 & 0.971 & 0.980 \\
\hline
\end{tabular}

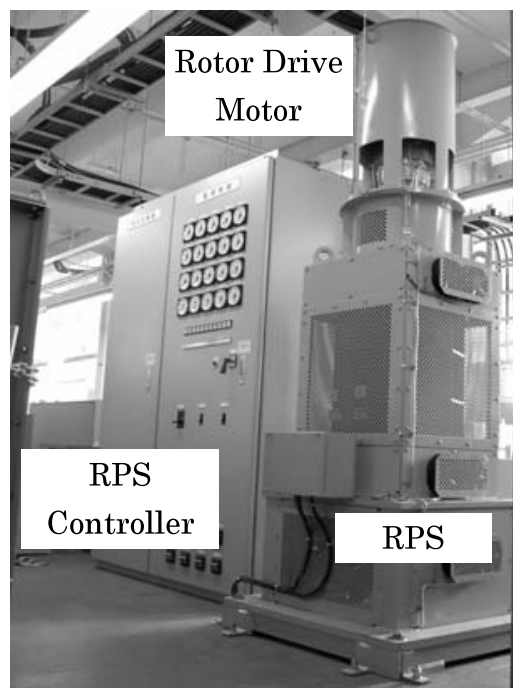

図 5 RPS 試作機と制御装置の概観

Fig. 5. Appearance of prototype RPS.
並列型において，前章で述べたように RPS システム全体 の等価インピーダンスの変化幅を大きくするため, また直 列型において，回転子巻線および固定子巻線が接続される 系統の電圧は同一階級と考えているため, 巻数比は 1 近く の值とした。並列型は回転子回転角度の可動範囲を制限可 能とし，回転継続しないものとした。

空隙長は, 本機の使用形態から考え, 回転角度を制御し 回転を殆どしないものについては励磁電流低減の面から小 さい方が好ましいが, 機器製作上から空隙は必要である為， $690 \mathrm{~V}$ 低圧コイルの場合には固定子鉄心外径により0.5〜 $2.0 \mathrm{~mm}$ 程度とした。しかしながら，6.6 kV の高圧コイルの 場合は更に空隙長を大きくせざるを得ない。

このような思想の基に試設計した並列型及び直列型（各

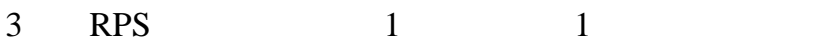

構造は, 基本的に風力発電設備のタワー内への設置や冷 却方式を考慮して立型とした。

本機の冷却方式は , 移相角を一定に制御し回転子が回転 継続しない時や回転子が高速回転しない場合に性能を発揮 する特性となっているため, 機器容量が大きくなると空気 冷却方式は成立せず, 固定子及び回転子を油冷却とせざる を得ない。表 1 に示した並列型と直列型でインピーダンス 值に相違が見られる理由は, 機器容量の相違から关れ光れ 異なる冷却方式を採用し，冷却方式の相違により巻線構成 が異なることによる。190kVA の並列型では空冷方式を， $30615 \mathrm{kVA}$ の直列型では油冷方式にて設計した。

以上の試設計に基き，50 kVA 並列/直列兼用 RPS の試作 機を設計・製作した。試作機の諸定数は表 1 に示した。

試作機は, 巻数比を極力 1 に近づけ , $440 \mathrm{~V}$ の低圧コイル であるため空隙長は最小の $0.5 \mathrm{~mm}$ とした。冷却は, ファ ンを使用した強制通風による空気冷却方式を採用した。し たがって試作機のインピーダンスは $190 \mathrm{kVA}$ 並列型の試設 計結果に近いが, 直列型と並列型兼用としたため若干の差 異が生じた。また, 駆動機容量は $7.5 \mathrm{~kW}$ となった。試作 機の高さ寸法は $2590 \mathrm{~mm}$, ベースでの平面寸法は $1000 \mathrm{~mm}$ 四方，重量は $1850 \mathrm{~kg}$ となった。

図 5 に $50 \mathrm{kVA}$ RPS 試作機の外観を示す。試作機単独の 特性試験を実施した結果，特性はほぼ設計值通りとなり良 好であることが確認できた。

\section{5. 風力発電システムへの適用と効果}

風力発電をはじめとする再生可能エネルギーによる発電 は，こ二数年間で急激な増加が計画されている一方，普及 に対する課題の一つとして電力系統への連系に関する問題 が挙げられる。風力発電は風という自然現象に依存してい るため, 風が強いと発電出力が大きくなり, 風が弱いと発 電出力が小さくなる。このような特性をもつ風力発電シス テムの電力系統への連系か増大すると, 電力需要に関係無 く供給電力が変動するため, 系統電圧や周波数への影響が 大きくなり，電力品質の悪化を招く。従って，電力会社は 電力系統への風力発電の導入を制限せざるを得ない状況に 
ある。もし，この風力発電システムによる電力安定供給が 実現できれば，より多くの発電システムの連系が可能とな り，導入が促進されると予想される。

風力発電システムの電力供給安定化の方策として, 風車 側のピッチ制御による出力制御による方法と, 電力貯蔵装 置などの外部機器により変動を補償する方法等が考えられ るが , 現状のシステムでは風車側の制御では応答が遅いた め, 日本のように風速の変動が大きい地域では急速な出力 変動を抑制できないという欠点があり，一方，外部機器は コストが十分競争力のあるレベルに達していない。

RPS は，これまで述べたように本体は巻線形誘導機の応 用設計で最適化が可能であり，回転子駆動も回転子に取り 付けたギアと駆動装置により実現可能である。また，応答 速度も風車のピッチ制御に比較して高速な応答が期待でき るので, 並列型 RPS の採用により系統に対する出力変動を 最小限に抑制することができると考える。图 6 に，風力発 電の出力変動を抑制するための RPS システム構成と動作概 念を示す。

RPS を風力発電設備と電力系統間に並列に接続し，有効 電力平準化制御または系統電圧一定制御を行う。RPS の並 列インピーダンスを抵抗とした有効電力平準化制御では， RPS で有効電力変動分の吸収を行い, 電力系統側に流出す る有効電力が一定の值になるように調整する。これにより， 系統側では電圧変動の抑制と周波数変動の抑制が行われる ため, 大規模な風力発電所への適用に向いている。この応 用例として，系統へ流出する許容電力を設定し，超過分の みRPS システムで調整することも可能である。この方式の 適用により，風車側は出力調整を最大出力を維持するよう に設定できるので, 発生電力量の増加が期待できる。系統 電圧一定制御では，RPS の並列インピーダンスをコンデン サまたはリアクトルとし, 静止形無効電力補償装置と同一 原理で, RPS による無効電力の調整を行い系統電圧を一定

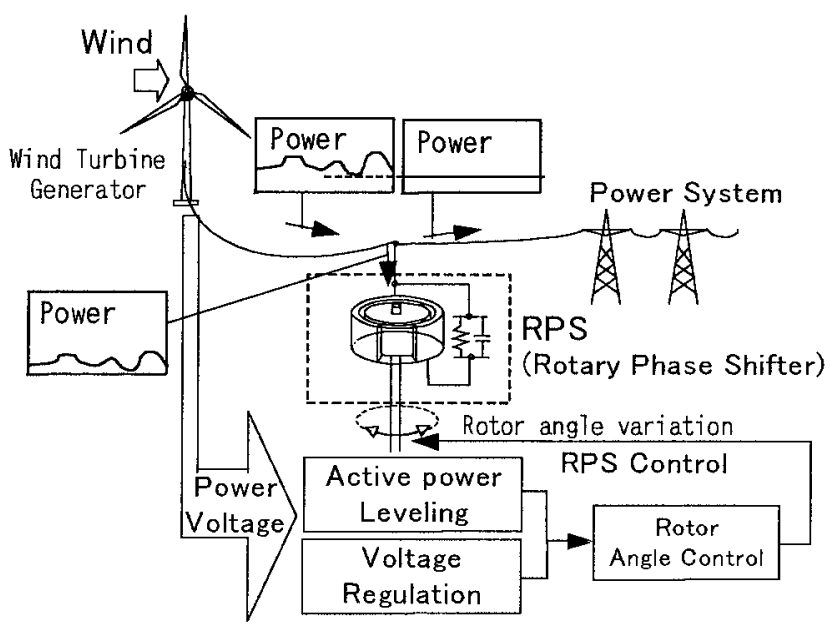

图 6 風力発電の出力変動抑制用 RPS システム構成

Fig. 6. RPS application for wind power load leveling.
に維持する。これによって短絡容量の小さい箇所や近辺に 需要家が接続された配電線への風力発電設備の導入もより 容易になると考える。

\section{6. シミュレーション解析と評価}

並列型 RPS の風力発電システムへの適用について, RPS の電力平準化制御と電圧一定化制御効果をシミュレーション 解析にて検証した。シミュレーション解析モデルを図 7 に示 す。風力機は $500 \mathrm{~kW}$ 力率 0.9 一定の誘導発電機を想定し, 風力発電機の出力変動は実測データから抽出した $0.17 \mathrm{pu} / \mathrm{s}$ のランブ状 1 秒間の変動とした。RPS は風力発電機端に接 続する。RPS 本体の容量は (12) 式と (13) 式から, 風力発電 機の $20 \%(100 \mathrm{~kW})$ の出力変動対策に適用可能な $50 \mathrm{kVA}$ とした。RPS 本体の定数は試作した $50 \mathrm{kVA}$ RPS の設計值 を利用する。RPS の並列インピーダンスは抵抗やコンデン サを選択して接続する。

並列型 RPS による電力平準化制御時のシミュレーション 結果を図 8 に示す。图 8(a) はRPS の並列インピーダンス を抵抗のみ ( $\mathrm{R}$ 型 $\mathrm{RPS}$ と表記) とした場合である。風力発 電機有効電力出力 $(\mathrm{PW})$ が $1 \mathrm{pu}$ から $1.17 \mathrm{pu}$ ヘランプ状 に変化するが, 電力平準化制御により RPS の移相角が $0^{\circ}$ から大きくなり，RPS インピーダンスが消費する有効電力 (PRPS) か増加することで風力発電機から電力系統へ出力 される有効電力 $(\mathrm{PG})$ は平準化されている。しかし， $\mathrm{R}$ 型 RPS では無効電力 (QRPS) 調整が不可であるので, 風力 発電機の無効電力 $(\mathrm{QW})$ の变化により風力発電機端電圧 (V) は低下する。図 8(b) は RPS の並列インピーダンスを 抵抗とコンデンサの並列接続 (RC 型 RPS と表記) とした 場合の電力平準化制御の結果である。電力平準化が達成さ れると同時に風力発電機端電圧低下も抑えられていること か確認できる。完全な電圧一定化か実現しないのはRPS の 制御自由度が回転子回転角度の 1 自由度のみであり，電力 平準化と電圧一定化を同時に制御できないことによる。

RPS を電圧一定化制御とし，RPS の並列インピーダン スをコンデンサのみ (C 型 RPS と表記) とした場合のシ ミュレーション結果を図 9 に示す。風力発電機の無効電力

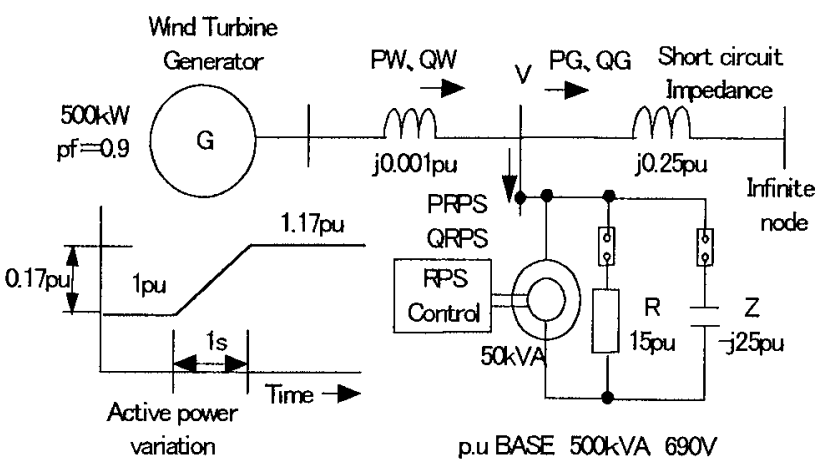

図 7 シミュレーション解析モデル

Fig. 7. Simulation model. 


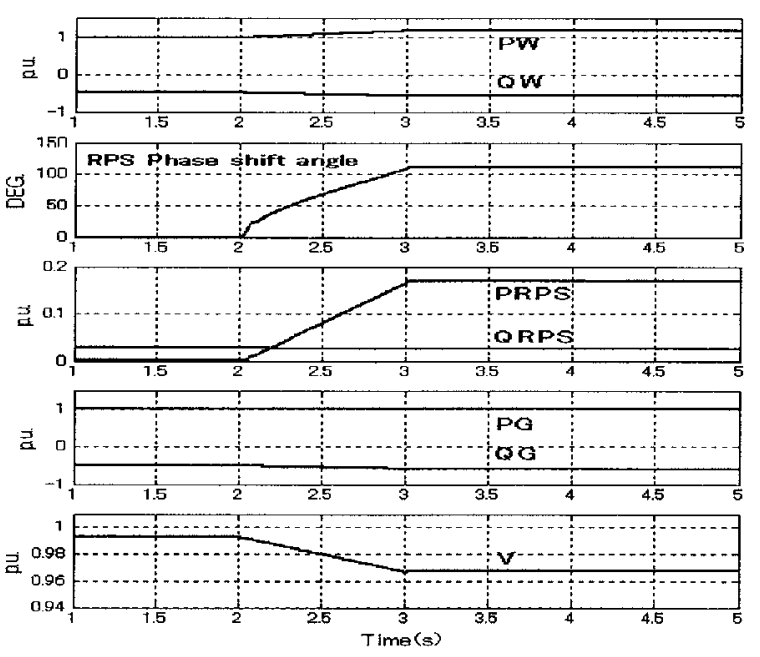

(a) In case of R type RPS
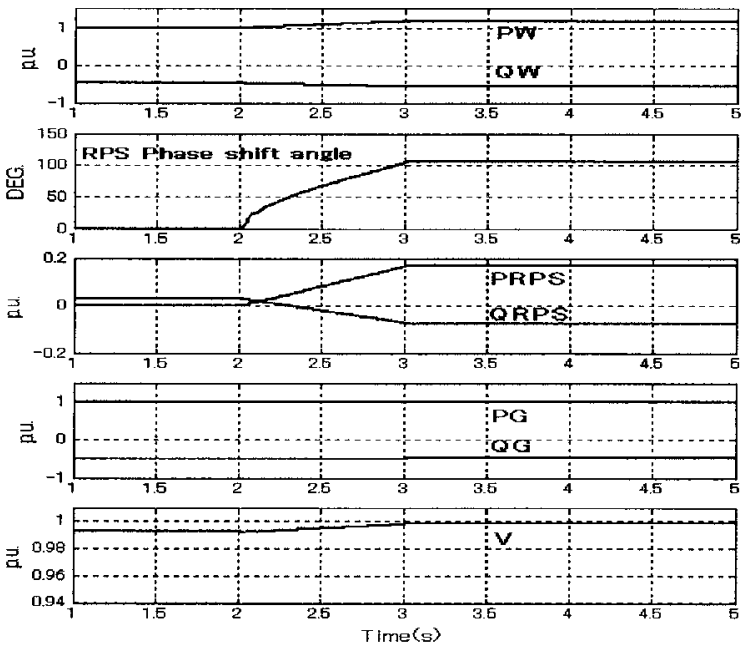

(b) In case of RC type RPS

図 8 RPS 電力平準化制御シミュレーション結果

Fig. 8. Simulation results of output power regulation control with shunt type RPS.

$(\mathrm{QW})$ 変化分が RPS の並列インピーダンスのコンデンサ により補償され，風力発電機端の電圧 $(\mathrm{V})$ が一定化され ていることが確認できる。

風力発電機容量 $(500 \mathrm{~kW})$ に対する系統短絡容量の比を パラメータとし，RPS の並列インピーダンスの構成，RPS 制御を電力平準化または電圧一定化とした場合の, 風力発 電機出力 $0.17 \mathrm{pu} / \mathrm{s}, 1$ 秒変動後における風力発電機端電圧 定常値を図 10 に示す。無限大母線電圧は，RPS 無し時の 風力発電機出力 $1 \mathrm{pu}$ 時に各短絡インピーダンス值において 風力発電機端電圧を $1 \mathrm{pu}$ とする值とした。

RPS 制御を電圧一定化制御（×）とした場合には，系統 短絡容量によらず風力発電機端電圧を一定化できることが 確認できる。電力平準化制御により，R 型 RPS (ム) の場 合には電圧低下が大きいが，RC 型 RPS $(O)$ とすること で電力平準化制御時においても電圧低下を小さい範囲に留 めることが可能であることが確認できる。
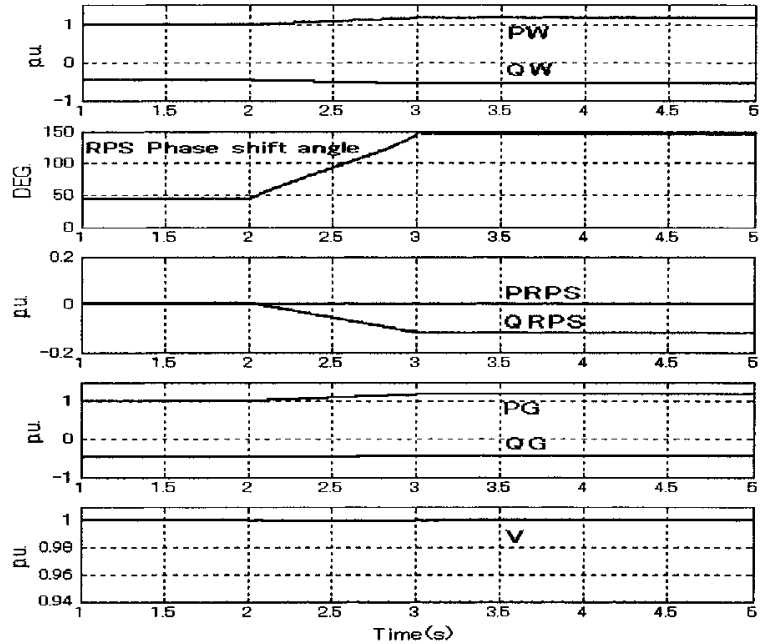

図 $9 \mathrm{C}$ 型 RPS 電圧一定化制御シミュレーション結果

Fig. 9. Simulation results of output voltage regulation control with shunt type RPS.

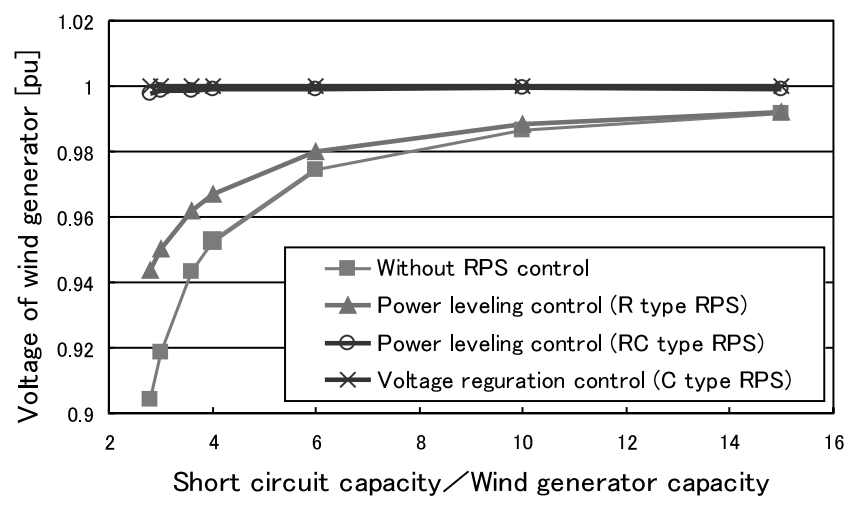

図 10 系統短絡容量と RPS 制御時の電圧変動

Fig. 10. Results of voltage fluctuation versus short circuit level.

\section{7. 工場試験と 評価}

RPS の適用例である並列型 RPS の基本的な静特性 ，およ び動特性を確認するため，50 kVA 試作 RPS 本体と風力発 電シミュレータ, 模擬送電線，模擬負荷を組合せ，検証試 験を実施した。風力発電シミュレータは, かご形誘導機 2 台を直結した MG-set と, 風力発電シミュレータ制御盤か ら成る。風力発電シミュレータ制御盤は, 発電機の出力を 正弦波や矩形波の他，任意のパターン状に制御することが できる。風力発電実機で計測した有効電力変動パターンを 風力発電シミュレータ制御盤に入力することにより，風力 発電実機の有効電力変動を模擬することも可能である。

〈7.1〉 システム構成 图 11 に工場試験装置のシステ 么構成を示す。また，構成機器の仕樣を表 2 に示す。配電 系統に接続された風力発電出力変動を抑制することを目的 に，RPS を風力発電端に接続した構成とした。

RPS の並列インピーダンスとして ，抵抗器もしくはコン デンサを接続できるようにしてあり，遮断器で抵抗器，コ 


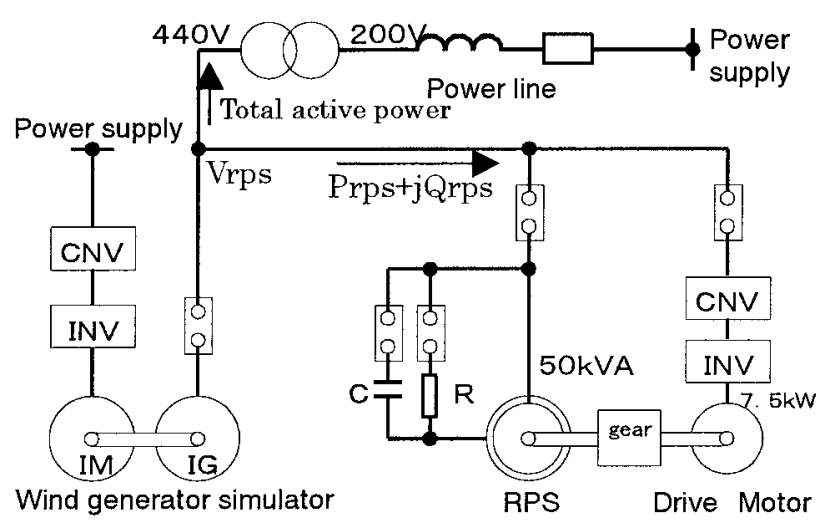

図 11 工場試験装置システム構成図

Fig. 11. System configuration for work test.

\section{表 2 試験機器の仕樣}

Table 2. Specifications of equipments.

\begin{tabular}{|l|l|}
\hline \multicolumn{1}{|c|}{ Equipments } & \multicolumn{1}{c|}{ Specifications } \\
\hline RPS & $4 \mathrm{P}-50 \mathrm{kVA}-440 \mathrm{~V}$ \\
\hline Drive Motor & $7.5 \mathrm{~kW}$ Induction Motor \\
\hline Resistor & $31 \Omega \cdot 16.4 \mathrm{~A} \times 4$ parallel $\times 3 \mathrm{ph}$ ase \\
\hline Capacitor & $880 \mathrm{~V} / \sqrt{3}-2.75 \mathrm{kVA} \times 5$ parallel $\times 3 \mathrm{ph}$ ase \\
\hline Inverter & $7.5 \mathrm{~kW}$ inverter \\
\hline $\begin{array}{l}\text { Wind Power } \\
\text { Generator } \\
\text { Simulator }\end{array}$ & $\begin{array}{l}\text { MG-set } 4 \mathrm{P}-55 \mathrm{~kW}-400 \mathrm{~V} \times 2 \\
\text { Wind Power Generator Controller }\end{array}$ \\
\hline
\end{tabular}

ンデンサを選択する。RPS システムは , 抵抗器を選択する ( $\mathrm{R}$ 型 RPS ) と有効電力の吸収量を調整でき , コンデンサを 選択する (C 型 RPS ) と，無効電力の出力を調整できるよ うになる。

\section{〈7. 2〉工場試験項目 工場試験で実施した主な試験項} 目を以下に示す。

（1）静特性試験 (R 型 RPS，C 型 RPS) 移相角を 0 度から 180 度まで 10 度毎変化させ, 安定状態で有効電力 $($ Prps ) , 無効電力 (Qrps) , 電圧 (Vrps) を測定した。

（2）動特性試験 (R 型 RPS，C 型 RPS) 回転子駆 動制御系の応答および特性を確認するためにステップ応答 試験および周波数応答試験を実施した。

(3) 風力発電シミュレータ組合せ試験 (R 型 RPS) 風力発電シミュレータの出力を変動させ , $\mathrm{R}$ 型 RPS に よる有効電力変動抑制効果を確認した。

（4）風力発電シミュレータ組合せ試験 (C 型 RPS) 風力発電シミュレータの出力を変動させ, $\mathrm{C}$ 型 RPS に よる電圧変動抑制効果を確認した。

〈7· 3〉 試験結果および評価 R 型 RPS 静特性試験結 果を図 12 に示す。有効電力 (Prps) が (12) 式で示した理 論通りに移相角の変化に伴い正弦波状に変化することか確 認でき，(12) 式の導出における理想的な RPS とした仮定

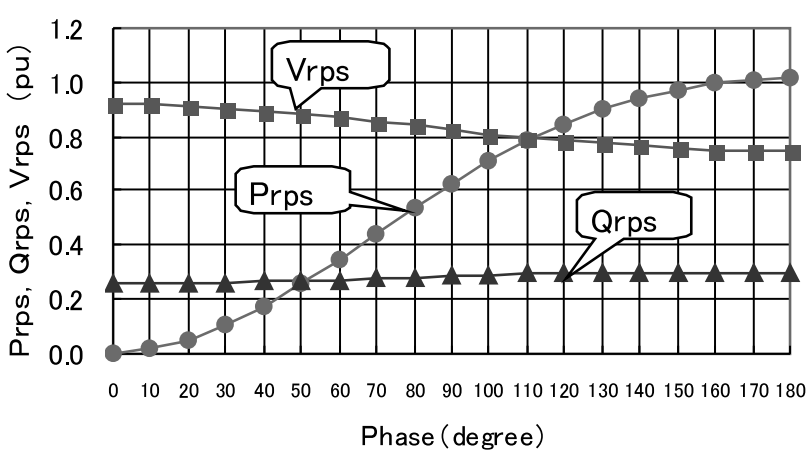

図 $12 \mathrm{R}$ 型静特性試験結果

Fig. 12. R-type static characteristic test.

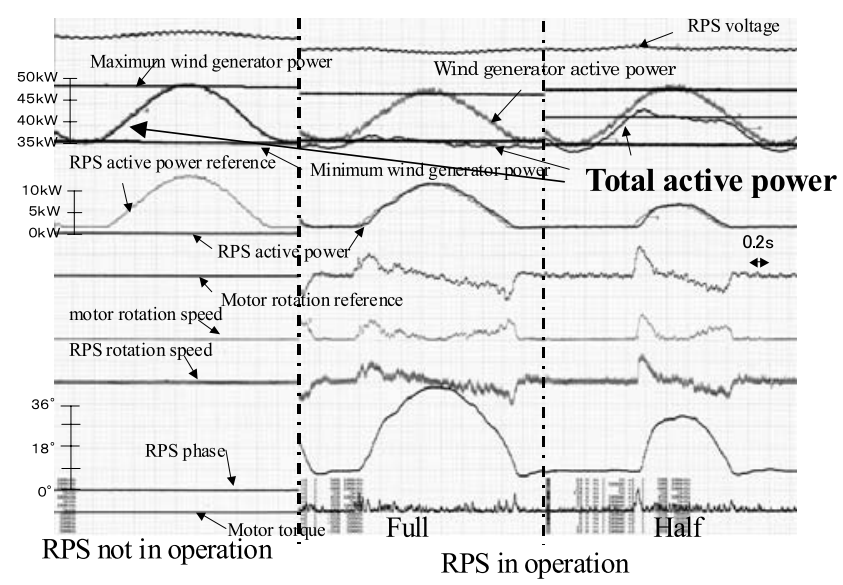

図 13 風力発電シミュレータ組合せ試験

( $\mathrm{R}$ 型, 正弦波変動)

Fig. 13. Combination test with wind generator simulator (R-type, sine wave).

の影響は小さいことがわかる。特に移相角が 0 度の場合有 効電力 Prps は $0 \mathrm{pu}$ で, 移相角が 180 度の場合に有効電力 Prps は最大となっている。

Qrps が0でないのは RPS 本体の励磁電流分である。ま た Prps 増加に伴う Vrps の低下は, RPS が系統側から Prps を受ける際の送電線路抵抗分による電圧低下である。

風力発電シミュレータの出力を直流分 $(35 \mathrm{~kW})+$ 正弦波 (振幅 $7.5 \mathrm{~kW}$, 周期 2 秒) で変化させた場合の試験結果を 図 13 に示す。図 13 中，縦点線で区切った各列の左から， RPS 適用無し時, R 型 RPS を設置し受電端有効電力 (Total active power) $35 \mathrm{~kW}$ を目標值とした電力平準化制御時，受 電端有効電力 $42.5 \mathrm{~kW}$ を目標値とした電力平準化制御時の 試験結果を示している。

受電端有効電力目標値を $42.5 \mathrm{~kW}$ とした場合に過渡的に 最大 $1.5 \mathrm{~kW}$ の目標值に対する偏差か甡じた。最大偏差は正 弦波変動 (振幅 $7.5 \mathrm{~kW}$ ) の中間点 (直流分 $35 \mathrm{~kW}+7.5 \mathrm{~kW}$ ) で生じている。この点は風力発電出力の変化速度が最大で あるため最大の制御偏差が生じたものと考える。本試験の 結果から受電端有効電力の変動を RPS 適用無しの場合に比 べて，約 $1 / 10$ 以下に低減できていることが確認できる。 


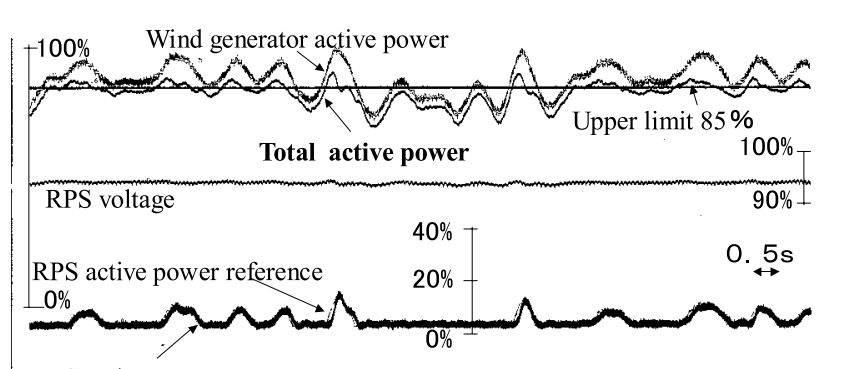

RPS active power

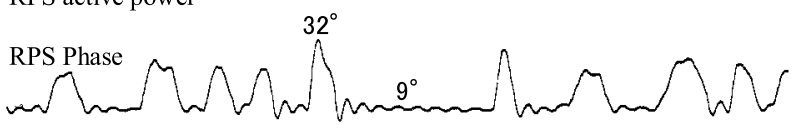

図 14 風力発電シミュレータ組合せ試験

( $\mathrm{R}$ 型, 風力パターン)

Fig. 14. Combination test with wind generator simulator (R-type, wind power fluctuation).

風力発電シミュレータの出力を実機風力変動パターンと したときの試験結果を図 14 に示す。系統許容電力値 (Upper limit $85 \%=50 \mathrm{~kW} \times 0.85=42.5 \mathrm{~kW}$ ) と設定し, 系統 許容電力値を超える風力機出力を $\mathrm{R}$ 型 RPS て吸収し, 受電 端有効電力を $85 \%(42.5 \mathrm{~kW})$ 以下に制限する。なお， $\mathrm{R}$ 型 RPS は有効電力の吸収のみが可能で, 有効電力出力が出来 ない為, 受電端有効電力は $42.5 \mathrm{~kW}$ で一定とはならない。

最大 $100 \%(50 \mathrm{~kW})$ に達する風力機の出力を, 目標と した $85 \%$ 以下に制限できている。目標値に対する最大偏差 は, 風力機出力が $80 \%$ 出力から $100 \%$ 出力八急速に変化す る際に, $1.8 \mathrm{~kW}$ 程度見られる。少の他の出力時には系統許 容電力值以下に受電端有効電力が制限されていることか確 認できる。

なお, 従来の開閉器と抵抗器の電力消費による風力発電 出力の系統許容電力値以下への抑制方法では, 風力発電出 力を直流分 $(35 \mathrm{~kW})$ と正弦波変動（振幅 $7.5 \mathrm{~kW}$ ，周期 2 秒) とし系統許容電力値を $35 \mathrm{~kW}$ と仮定した場合, 風力発 電出力の最大值 $50 \mathrm{~kW}$ を $35 \mathrm{~kW}$ 以下となるように抵抗器 バンクを投入する。最大值 $50 \mathrm{~kW}$ を $35 \mathrm{~kW}$ に制限しても 抵抗量を連続的に可変できないため, 正弦波変動は平準化 できない。したがって抵抗器投入時には直流分 $20 \mathrm{~kW}$ と正 弦波変動（振幅 $7.5 \mathrm{~kW}$ ，周期 2 秒）となり，RPS を適用し た場合の $35 \mathrm{~kW}$ ほぼ一定に比較し, 電力変動か残り受電端 有効電力量 $(\mathrm{Wh})$ が小さくなる。 RPS 適用による電力変 動平準化により，系統許容電力值以下での受電端有効電力 量の向上が可能となる。

これらのRPS 試作機を用いた試験結果から，RPS の適 用により秒オーダの風力機出力変動の平準化が可能であり, 風力発電機の受電端有効電力量を最大限活用することが可 能であると言える。

\section{8. まとめ}

回転形位相調整機（RPS）を風力発電機の電力变動補償 装置として並列型構成で適用する場合のシステム構成，原
理，計算機シミュレーション解析による性能検証，試作機 と模擬送電線系統の組合せ試験による性能検証試験結果を 報告した。試作機を用いた試験から，以下のことが明らか となった。

（1） RPS の移相角に対する RPS システム全体の入力 電力等のシステム特性は理論式と良く一致する。

（2）RPS は秒オーダの応答速度が実現可能で, 風力発 電機における秒単位周期以上の電力変動平準化入適 用でき, 風力発電設備の出力安定化が可能となる。

（3）系統許容電力値を超える風力発電機出力をRPS で 連続可変的に吸収し, 受電端有効電力を系統許容電 力値以下に制限できるため, 系統許容電力值以下で 風力発電設備による受電端有効電力量を向上するこ とが可能となる。

なお本稿では試験結果を記述していないが，RPS の並列 インピーダンスをコンデンサとした試作機試験結果にて， 電力平準化の応答特性と同樣に秒単位の電圧变動の抑制が 可能であることも確認している。

RPS の特徵として, 巻線形誘導機に類似した主機構造に よる過電流耐量が大きいことや，回転子駆動装置による発 生高調波が極めて小さいことが挙げられ, パワーエレクト ロニクス機器や電力貯蔵装置に比較し低コスト化が実現可 能と考えている。

今後は, 実機風力発電機と組合せたフィールド試験を行 い, 実負荷での性能検証と, 風力発電設備立地点の環境下 で長期信頼性の検証を行う予定である。

本論文では回転形位相調整機の並列型の試験検証結果を 述べたが，系統間に直列接続する直列型とした場合，異系 統間の連系や潮流制御が可能である。将来の分散型電源増 大時における系統安定化技術の選択肢として今後併せて研 究を進めていく予定である。

(平成 15 年 5 月 6 日受付, 平成 15 年 11 月 20 日再受付)

$$
\text { 文献 }
$$

(1) M. Molinas, J. Kobuchi, S. Takahashi, and R. Shimada: "Flywheel effect in power plants with an induction frequency converter', PESC'98 Record, p.8403 (1998)

(2) T. Nohara, H. Senaha, T. Kageyama, and T. Tsukada: "Successful commercial operation of doubly-fed adjustable-speed flywheel generating system", Proc. CIGRE/IEE Jpn. Joint Colloq. Rotating Electric Machinery Life Extension, Availability Improvement, and Development of New Machinary, Paper(2-2), pp.1-6 (1997)

( 3 ) M. Molinas, H. Nakamura, H. Koyanagi, and R. Shimada: "Analytical and experimental study of a Rotary Phase Shifter for Power System Applications", T. IEE Japan, Vol.120-B, No.10, pp.1336-1342 (2000-10)

( 4 ) H. Yamamoto, Y. Miyazaki, Y. Noro, T. Ishizuki, Y. Sato, and R. Shimada: "Application of Rotary Phase Shifter on the Decentralized Power System", Proc. of IERE Zurich Workshop Implication of Decentralized Power Generation, pp.107-119 (2002)

( 5 ) H. Nakamura, A. Koyanagi, M. Molinas, T. Matsukawa, Y. Sato, and R. Shimada: "Study on Power Fluctuation Compensation of Wind Turbine Generator by Rotary Phase Shifter", 2000 National Convention Record IEE Japan, Industry Application Society, Vol.1, pp.169-170 (2000) (in Japanese) 中村浩和・小柳明大・マルタモリナス・松川達哉・佐藤義久・嶋田 隆一: 「回転型移相機による風力発電変動補償」, 平成 12 年度電気学 会産業応用部門大会講演論文集, Vol.1, pp.169-170 (2000) 
(6) A. Koyanagi, H. Nakamura, Y. Suzuki, M. Molinas, and R. Shimada: "Study on Power Fluctuation Compensation of Wind Turbine Generator by Flywheel", 2000 National Convention Record IEE Japan, Industry Application Society, Vol.2, T-67, p.715 (2000) (in Japanese)

小柳明大・中村浩和・鈴木康慎・マルタモリナス・嶋田隆一：「可 変速フライホイール発電機による風力発電変動補償」, 平成 12 年度 電気学会産業応用部門大会講演論文集, T-67, p.715 (2000)

( 7 ) H. Nakamura, A. Koyanagi, Y. Suzuki, N. Eguchi, Y. Sato, and R. Shimada: "Study on Flywheel Capacity of the Power Compensator for Wind Turbine Generator", T. IEE Japan, Vol.122-D, No.3, pp.247-252 (2002-3) (in Japanese)

中村浩和 - 小柳明大 · 鈴木康慎 - 江口直也 ·佐藤義久 - 嶋田隆一 :

「風力発電におけるフライホイール蓄積容量に関する研究」, 電学論 D, 120, 3, pp.247-252 (2002-3)

(正員) 1967 年 3 月 10 日生。1992 年 3 月九州 工業大学大学院設計生産工学 (制御) 専攻博士前 期課程修了。同年 (株) 東芝入社。現在 , 同社電 カ・社会システム技術開発センターにおいて電力 系統の解析と電力機器に関する制御システムの研 究開発に従事。計測自動制御学会会員。

石月 照之 (正員) 1958 年 5 月 13 日生。1983 年 3 月早稲

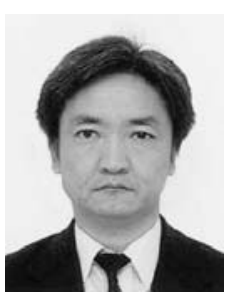
田大学大学院理工学研究科 (電気工学修士) 卒業。 同年 4 月 (株) 東芝入社。現在 , 同社火力・水力事 業部にて, 主として水力発電システムのエンジニ アリング業務に従事するとともに可变速揚水発電 設備など電カシステム向可変速応用製品の適用・ 開発に従事。

工 藤 俊 明 (正員) 1949 年 6 月 3 日生。1968 年 3 月青森県

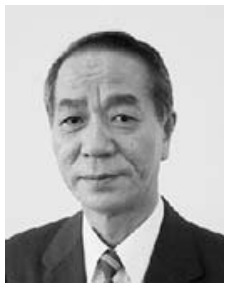
立弘前工業高校卒業。同年 4 月東京芝浦電気 (株) (現 (株) 東芝) 入社。現在 , 同社電力・社会シス テム技術開発センターにて , モータドライブ , パ ワエレ応用機器の開発に従事。2000 年電気科学 技術奨励賞 (オーム技術賞)。

影山 隆久 (正員) 1960 年 9 月 25 日生。1985 年 3 月筑波

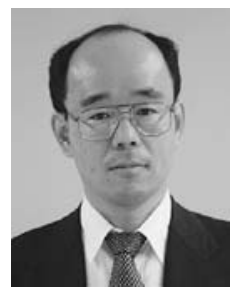
大学大学院理工学研究科修了。同年 4 月 (株) 東 芝入社。現在 , 同社発電制御システム部にて , 可 变速揚水発電システム, フライホイール他 , パワ エレ応用機器の開発に従事。2000 年電気学会進 歩賞。

南 波

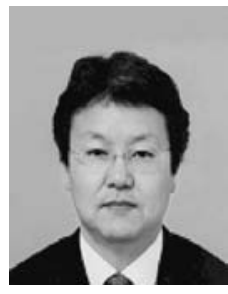

野 呂 康 宏

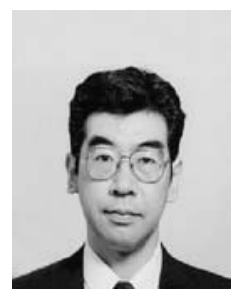

嶋田 隆 - (正員) 1948 年 1 月 31 日生。1970 年東京工業大

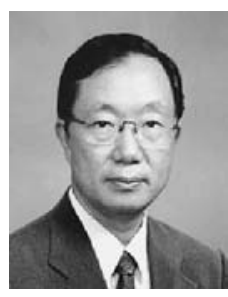
学工学部電気工学科卒業。1975 年東京工業大学大 学院理工学研究科電気工学科博士課程卒業, 工学 博士。日本原子力研究所にて大型卜カマク JT-60 核融合装置の開発に従事 , 1984 年大型卜カマク開 発部 JT-60 第一開発室電源開発グループリーダー， 1986 年実験運転責任者。1988 年東京工業大学工 学部電気電子工学科助教授, 1990 年教授, 同年原 子炉工学研究所教授, 総合理工学研究科創造エネルギー専攻。主とし て核融合炉工学, プラズマ制御の研究, 大電力システム, 電力工学, 電力貯蔵, パワーエレクトロニクスの研究に従事。電気学会論文賞 (1976 年，2000 年)，進歩賞 (1985 年)。 